\title{
TU/e EmonONEN

\section{Energy flexibility potential of a small district connected to a district heating system}

\section{Citation for published version (APA):}

Luc, K. M., Li, R., Xu, L., Nielsen, T. R., \& Hensen, J. L. M. (2020). Energy flexibility potential of a small district connected to a district heating system. Energy and Buildings, 225, [110074].

https://doi.org/10.1016/j.enbuild.2020.110074

\section{Document license:}

TAVERNE

DOI:

10.1016/j.enbuild.2020.110074

Document status and date:

Published: 15/10/2020

\section{Document Version:}

Publisher's PDF, also known as Version of Record (includes final page, issue and volume numbers)

\section{Please check the document version of this publication:}

- A submitted manuscript is the version of the article upon submission and before peer-review. There can be important differences between the submitted version and the official published version of record. People interested in the research are advised to contact the author for the final version of the publication, or visit the $\mathrm{DOI}$ to the publisher's website.

- The final author version and the galley proof are versions of the publication after peer review.

- The final published version features the final layout of the paper including the volume, issue and page numbers.

Link to publication

\section{General rights}

Copyright and moral rights for the publications made accessible in the public portal are retained by the authors and/or other copyright owners and it is a condition of accessing publications that users recognise and abide by the legal requirements associated with these rights.

- Users may download and print one copy of any publication from the public portal for the purpose of private study or research.

- You may not further distribute the material or use it for any profit-making activity or commercial gain

- You may freely distribute the URL identifying the publication in the public portal.

If the publication is distributed under the terms of Article 25fa of the Dutch Copyright Act, indicated by the "Taverne" license above, please follow below link for the End User Agreement:

www.tue.nl/taverne

Take down policy

If you believe that this document breaches copyright please contact us at:

openaccess@tue.nl

providing details and we will investigate your claim. 


\title{
Energy flexibility potential of a small district connected to a district heating system
}

\author{
Katarzyna M. Luc ${ }^{\mathrm{a}, *}$, Rongling Li ${ }^{\mathrm{a}}$, Luyi Xu ${ }^{\mathrm{b}}$, Toke R. Nielsen ${ }^{\mathrm{a}}$, Jan L.M. Hensen ${ }^{\mathrm{b}}$ \\ a Department of Civil Engineering, Technical University of Denmark, Kgs. Lyngby, Copenhagen, Denmark \\ ${ }^{\mathrm{b}}$ Department of the Built Environment, Eindhoven University of Technology, Eindhoven, The Netherlands
}

\section{A R T I C L E I N F O}

\section{Article history:}

Received 30 November 2019

Revised 8 March 2020

Accepted 17 April 2020

Available online 9 July 2020

\section{Keywords:}

Energy flexibility

District heating

Building thermal mass

Load shifting

\begin{abstract}
A B S T R A C T
The flexibility of thermal energy systems can support the energy system as a whole in integrating a large share of fluctuating renewable energy sources. The current paper investigates the flexible operation potential of a small district with buildings connected to a district heating network. In the study, the thermal mass of the buildings was utilized as heat storage and the investigation was performed for the heating season. The load shifting scenarios used were created based on the available information on heat load and dynamic heat production cost in the Greater Copenhagen district heating system. The results of the study indicate that the applied strategy of load shifting is highly effective. The achieved load shifting in all schedule-based scenarios was between $41 \%$ and $51 \%$. The applied scenarios resulted in an increased peak demand and energy use. However, the increased energy use occurs mostly during the low-load periods, when the heat production prices are lower. It was also shown, that the increased peak can be partially mitigated by using the appropriate control strategies.
\end{abstract}

(c) 2020 Elsevier B.V. All rights reserved.

\section{Introduction}

The growing share of fluctuating renewable energy sources, such as wind and solar power, in the energy system production mix creates a challenge for the system, as the energy supply can no longer be fully controlled. District heating has been shown to have a significant potential to support the integration of fluctuating renewable energy sources into power systems by offering costeffective flexibility $[20,25]$ and to be able to accommodate temporary large power oversupply [29]. This is due to the characteristics of the thermal energy systems that have both greater inertia than power systems and are significantly less sensitive to the mismatch between the demand and supply. Utilizing this flexibility potential can also have significant benefits for the district heating systems. The sources of flexibility in thermal networks are the heat (or cold) of the heat (or cold) carrier, thermal storage devices (e.g. heat storage tanks) and thermal inertia of the buildings connected to the system [34].

Peak and reserve boilers in district heating systems are typically heat-only boilers using natural gas or oil $[1,8]$, so limiting their use is beneficial both from the financial and environmental point of view. Eliminating daily load variation would lead also to

\footnotetext{
* Corresponding author.

E-mail address: kamalu@byg.dtu.dk (K.M. Luc).
}

less need for peak power capacity and thus potentially lower investment costs, improved utilization of industrial excess heat, easier optimization of system operation and potentially less need for maintenance thanks to the smoother operation [15]. Thermal energy storage using storage tanks in the district heating system was shown also to be a method to obtain both primary energy savings and cost savings [36].

The thermal storage capacity of buildings connected to the district heating system can also be utilized as short-term heat storage to support the operation of this system. In contrast to the traditional heat storage methods as the heat storage tanks and water pits located on the supply side of the system, such solution does not require further capital investment in the storage capacity and it is readily available already in the existing systems. A research performed in two residential buildings with large thermal mass in Finland indicated the maximum heat load can be reduced for 23 hours by $20-25 \%$ on average [17]. A later pilot test performed in five Swedish multifamily residential buildings has shown, that buildings with concrete structure can tolerate relatively large variations in heat delivery without compromising the thermal comfort [19]. There, the results indicate that activating storage of 0.1 $\mathrm{kWh} / \mathrm{m}^{2}$ of floor area in buildings with large thermal mass will only sporadically result in indoor temperature variations greater than $\pm 0.5^{\circ} \mathrm{C}$. On the scale of a whole district heating system it has been shown, that the demand side management (DSM) can be used to mitigate the effect of night set back [2] For that purpose, 
it was determined that buildings with short heating up time are the most suitable for the peak load reduction due to load shifting. The significant potential of thermal energy storage in the buildings' thermal mass has also been shown in the context of compensating the reduced heat output of the district heating system [32].

The flexibility and storage capacity of the thermal energy systems can be used to support power-to-heat solutions and utilize the oversupply of energy generated from fluctuating renewable energy sources. The strategies and technologies coupling thermal and electrical systems, such as flexible operation of CHP units, heat storage and electric boilers were determined to be the most costeffective for this purpose [20]. Heat storage in stratified heat storage tanks was shown to be an effective method of supporting the wind power integration [6]. Due to the growing interest in the demand-side management and system integration, the storage potential of the building sector is also extensively researched. There are many studies focusing on the use of buildings heated with the use of heat pumps or heated and cooled using HVAC units as heat storage, as such technologies result in direct connection to the power system. As such, they have the potential to be used to support the power system. It has been suggested, that electricity tariffs can be used as incentive to shift the heat pump load to off-peak hours [23], It was also concluded that the redistribution of energy use in time can lead to higher total energy use [4,23]. However, the increased energy use does not have to lead to increased procurement costs, neither for a supplier, nor a consumer [23].

The case study was based on an existing area of an urban district heating network with total heated floor area of $135257 \mathrm{~m}^{2}$. Two studies using the same area as a case study were done by Foteinaki et al. [13] and by Cai et al. [5]. The first of them focused on the energy flexibility of an individual low-energy residential building, while the second presented a Demand-Side Management (DSM) method for a district heating network aimed at improving the network efficiency and congestion management.

The current study includes load control strategies based both on the heat load in the district heating system and on the heat generation costs. The main goal of the current study was to investigate the thermal energy flexibility that realistically can be provided for the district heating system by a local district heating network, taking into account characteristics of buildings in the area, occupants' comfort and current heat market setup. Two methods of control were applied - schedule-based and price-based indoor temperature setpoint control. Thermal characteristics of the buildings were also accounted for. To the best knowledge of the authors, not many studies have included the active demand response based on the heat production costs to benefit the district heating system. Moreover, most of the studies on flexibility focus on the level of a single building, not on the level of a district. The utilized approach allowed also for comparing the results of applied strategies in different building types. The results of the study can help to optimize district heating system operation and can potentially impact future operation of the district heating systems.

\section{Methods}

This section describes the case study area, the model used in the investigation and the steps of the performed analysis.

\subsection{Modelling approach}

The model was implemented in Modelica [24]. Modelica is an object-oriented, multi-domain modelling language for componentoriented modelling. It is domain neutral and allows for modelling of systems containing subcomponents from different domains, including their control. A detailed description of the advantages and disadvantages of using equation-based languages for building energy modelling is described by Wetter, Bonvini, \& Nouidui [37]. The model was compiled and simulated with Dymola [10]. The solver used in the study was the standard DASSL solver included in Dymola.

\subsection{Building models}

To be able to investigate the interaction between the buildings and the district heating system and model thermal inertia of buildings, simplified physical models of buildings in the study area were used in the model. The part of the network investigated in detail supplies heat to 1 office building, 18 multi-family residential buildings and to 31 row houses, of total $135257 \mathrm{~m}^{2}$ heated floor area. The buildings are representative for the Danish building stock. Most of the buildings supplied are new residential buildings and fulfil the requirements of building class 2015 or building class 2020 as set in $[8,31]$. According to the Building Regulations 2015, the building should not use more than $30.0 \mathrm{kWh} / \mathrm{m}^{2}+1000 / \mathrm{A}$ of primary energy per year, where $A$ is the heated floor area. For the energy class 2020 the primary energy use should not exceed 20.0 $\mathrm{kWh} / \mathrm{m}^{2}$.

The building models used were based on the MixedAir component from the Buildings library [39]. A detailed description of the assumptions made in the room model can be found in [38]. The model includes temperature, pressure and species balance equations inside the room volume and was validated using ANSI/ASHRAE Standard 140 cases 610, 620, 630, as well as 600, 600FF and 900 and 90FF for a low and high mass building [26,38]. Each of the buildings was modelled as a single zone with four external walls, a floor slab and a roof. Missing building geometry data, such as total window area, was generated using TEASER package [28]. In each model, the window area was distributed equally between all four walls and modelled as a single window on each wall, with no overhangs, side fins or shading. As the investigation focuses on the heating season, the lack of additional shading and simplified window modelling should not have a significant effect on the results of the study. The area of the thick internal walls was estimated based on the floor plan of one of the representative residential buildings in the area and was assumed to be 1.2 times the area of external walls for all of the modelled buildings. The area of the internal floors was assumed to be the area of the floor slab multiplied by ( $n-1)$, where $n$ is the number of floors. Both thick internal walls and internal floors were included in the internal walls area in the model. Ventilation rate was assumed to be constant in all of the buildings modelled and equal to $0.3 \mathrm{l} / \mathrm{s}$ per $\mathrm{m}^{2}$, according to $[8,31]$. In the new buildings, the heat exchanger efficiency was assumed to be $80 \%$. In the old buildings, all the ventilation was modelled as infiltration and no heat recovery was assumed. To reflect the impact of the furniture mass on the thermal capacity of the buildings, the air thermal capacity was set to 2.5 of the default value.

The input data used in the building models for the different building groups is summarized in Table 1 . The buildings in the area were divided into 3 groups: new residential buildings, old buildings and an office building. For the new buildings, constructions based on the data for one of the buildings in the area representative for the rest of the new building stock were used. For the old buildings, the constructions were assumed based on the data available in TABULA database [30]. For the old buildings, the thermal mass of internal floor was ignored, as the floor construction in such buildings is usually made of wood and has no significant storage capacity.

Fig. 1 presents the schematics of the building model together with external inputs to the model. 
Table 1

Input for the building model for different building groups.

\begin{tabular}{|c|c|c|c|}
\hline & New residential buildings & $\begin{array}{l}\text { Old buildings - internal gain like the } \\
\text { offices }\end{array}$ & Office building \\
\hline External wall construction & $\begin{array}{l}108 \mathrm{~mm} \text { brick, } 25 \mathrm{~mm} \text { air gap, } 275 \mathrm{~mm} \\
\text { mineral wool, } 150 \mathrm{~mm} \text { concrete U-value } \\
0.125 \mathrm{~W} / \mathrm{m}^{2} \mathrm{~K}\end{array}$ & $360 \mathrm{~mm}$ brick, U-value $1.50 \mathrm{~W} / \mathrm{m}^{2} \mathrm{~K}$ & $\begin{array}{l}108 \mathrm{~mm} \text { brick, } 25 \mathrm{~mm} \text { air gap, } 275 \mathrm{~mm} \\
\text { mineral wool, } 150 \mathrm{~mm} \text { concrete } \mathrm{U} \text {-value } \\
0.125 \mathrm{~W} / \mathrm{m}^{2} \mathrm{~K}\end{array}$ \\
\hline $\begin{array}{l}\text { Internal wall and floor } \\
\text { construction }\end{array}$ & $200 \mathrm{~mm}$ concrete & $\begin{array}{l}200 \mathrm{~mm} \text { brick, internal floors not } \\
\text { included }\end{array}$ & $200 \mathrm{~mm}$ concrete \\
\hline Roof construction & $\begin{array}{l}10 \mathrm{~mm} \text { gypsum, } 200 \mathrm{~mm} \text { air gap, } 150 \mathrm{~mm} \\
\text { concrete, } 380 \mathrm{~mm} \text { mineral wool, } 40 \mathrm{~mm} \\
\text { render U-value } 0.085 \mathrm{~W} / \mathrm{m}^{2} \mathrm{~K}\end{array}$ & $\begin{array}{l}20 \mathrm{~mm} \text { wooden planks, } 50 \mathrm{~mm} \\
\text { mineral wool U-value } 0.62 \mathrm{~W} / \mathrm{m}^{2} \mathrm{~K}\end{array}$ & $\begin{array}{l}10 \mathrm{~mm} \text { gypsum, } 200 \mathrm{~mm} \text { air gap, } 150 \mathrm{~mm} \\
\text { concrete, } 380 \mathrm{~mm} \text { mineral wool, } 40 \mathrm{~mm} \\
\text { render U-value } 0.085 \mathrm{~W} / \mathrm{m}^{2} \mathrm{~K}\end{array}$ \\
\hline Floor slab construction & $\begin{array}{l}10 \mathrm{~mm} \text { wooden flooring, } 40 \mathrm{~mm} \text { render, } \\
15 \mathrm{~mm} \text { hard insulation, } 290 \mathrm{~mm} \text { foam } \\
\text { concrete, } 100 \mathrm{~mm} \text { concrete, } 150 \mathrm{~mm} \text { hard } \\
\text { insulation U-value } 0.094 \mathrm{~W} / \mathrm{m}^{2} \mathrm{~K}\end{array}$ & $\begin{array}{l}20 \mathrm{~mm} \text { wooden planks, } 90 \mathrm{~mm} \text { air } \\
\text { gap U-value } 1.45 \mathrm{~W} / \mathrm{m}^{2} \mathrm{~K}\end{array}$ & $\begin{array}{l}10 \mathrm{~mm} \text { wooden flooring, } 40 \mathrm{~mm} \text { render, } \\
15 \mathrm{~mm} \text { hard insulation, } 290 \mathrm{~mm} \text { foam } \\
\text { concrete, } 100 \mathrm{~mm} \text { concrete, } 150 \mathrm{~mm} \text { hard } \\
\text { insulation U-value } 0.094 \mathrm{~W} / \mathrm{m}^{2} \mathrm{~K}\end{array}$ \\
\hline Window glazing & 3-layer energy pane U-value $0.67 \mathrm{~W} / \mathrm{m}^{2} \mathrm{~K}$ & Double pane U-value $1.45 \mathrm{~W} / \mathrm{m}^{2} \mathrm{~K}$ & 3-layer energy pane $\mathrm{U}$-value $0.67 \mathrm{~W} / \mathrm{m}^{2} \mathrm{~K}$ \\
\hline Window frame U-value & $1.4 \mathrm{~W} /\left(\mathrm{m}^{2} \cdot \mathrm{K}\right)$ & $1.4 \mathrm{~W} /\left(\mathrm{m}^{2} \cdot \mathrm{K}\right)$ & $1.4 \mathrm{~W} /\left(\mathrm{m}^{2} \cdot \mathrm{K}\right)$ \\
\hline Ventilation & $0.3 \mathrm{l} / \mathrm{s}$ per $\mathrm{m}^{2}$ & - & $0.6 \mathrm{l} / \mathrm{s}$ per $\mathrm{m}^{2}$ \\
\hline Infiltration & $0.1 \mathrm{l} / \mathrm{s}$ per $\mathrm{m}^{2}$ & $0.3 \mathrm{l} / \mathrm{s}$ per $\mathrm{m}^{2}$ & $0.1 \mathrm{l} / \mathrm{s}$ per $\mathrm{m}^{2}$ \\
\hline
\end{tabular}

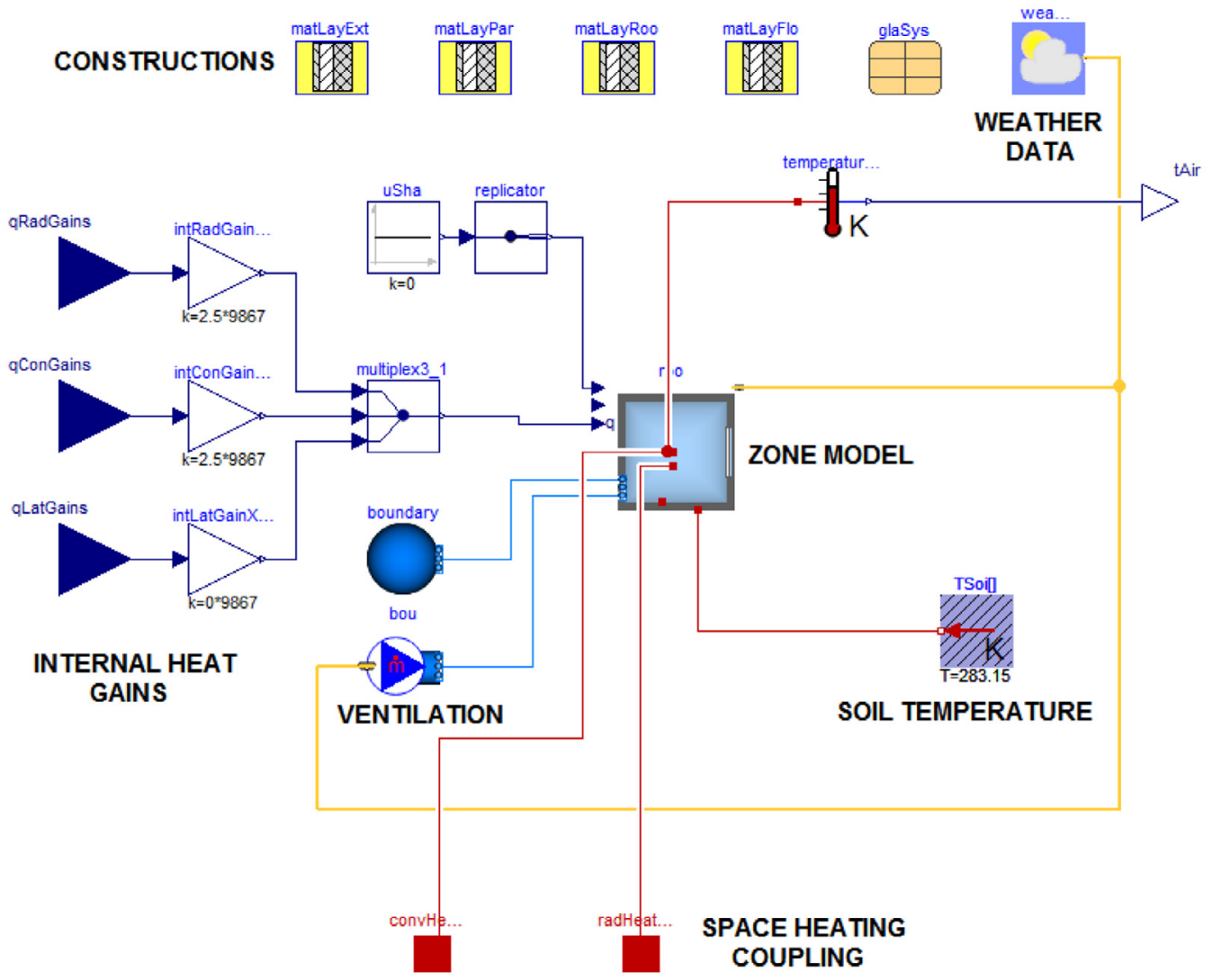

Fig. 1. Schematics of a building model.

\subsection{Customer substation models}

The concept of the customer substation model used in the current study is similar to the concept used in [18]. As the investigation was focused on the flexibility available through changing the internal temperature setpoint and activation of building thermal mass, only space heating load was included. The substation modelled is an indirect substation, with primary and secondary side hydraulically separated. Mass flow on the primary side was controlled with a valve based on the required supply temperature on the secondary side. For the heat exchanger model, a constant efficiency of $80 \%$ is assumed.

The required supply temperature for the buildings' heating system was determined using a weather compensation curve and de- pended on the ambient temperature and on the building type. The parameters of the weather compensation curve were chosen to represent a heating system with low temperature radiators for the new residential buildings and the office building and high temperature radiators in the old buildings. The highest supply temperatures were used at the temperature of $-12^{\circ} \mathrm{C}$ and below (design temperature for Denmark). The heat exchange between the building model and the substation was modelled with the use of radiators that were set to exchange heat with the heat ports in the building models. The radiators were sized based on building heat demand. The mass flow in the secondary loop was controlled by comparing the air temperature in the building with the temperature setpoint. The maximum mass flow in the secondary loops was calculated based on the design heat load of the building and de- 
Table 2

Input parameters for the district heating substation model.

\begin{tabular}{ll}
\hline Parameter & Value \\
\hline Design temperatures in the secondary loop - new and renovated buildings & $55 / 45 / 20^{\circ} \mathrm{C}$ \\
Design temperatures in the secondary loop - old buildings & $75 / 65 / 20^{\circ} \mathrm{C}$ \\
DH supply temperature & Constant $80^{\circ} \mathrm{C}$ \\
Heat exchanger efficiency & Constant $80 \%$ \\
\hline
\end{tabular}

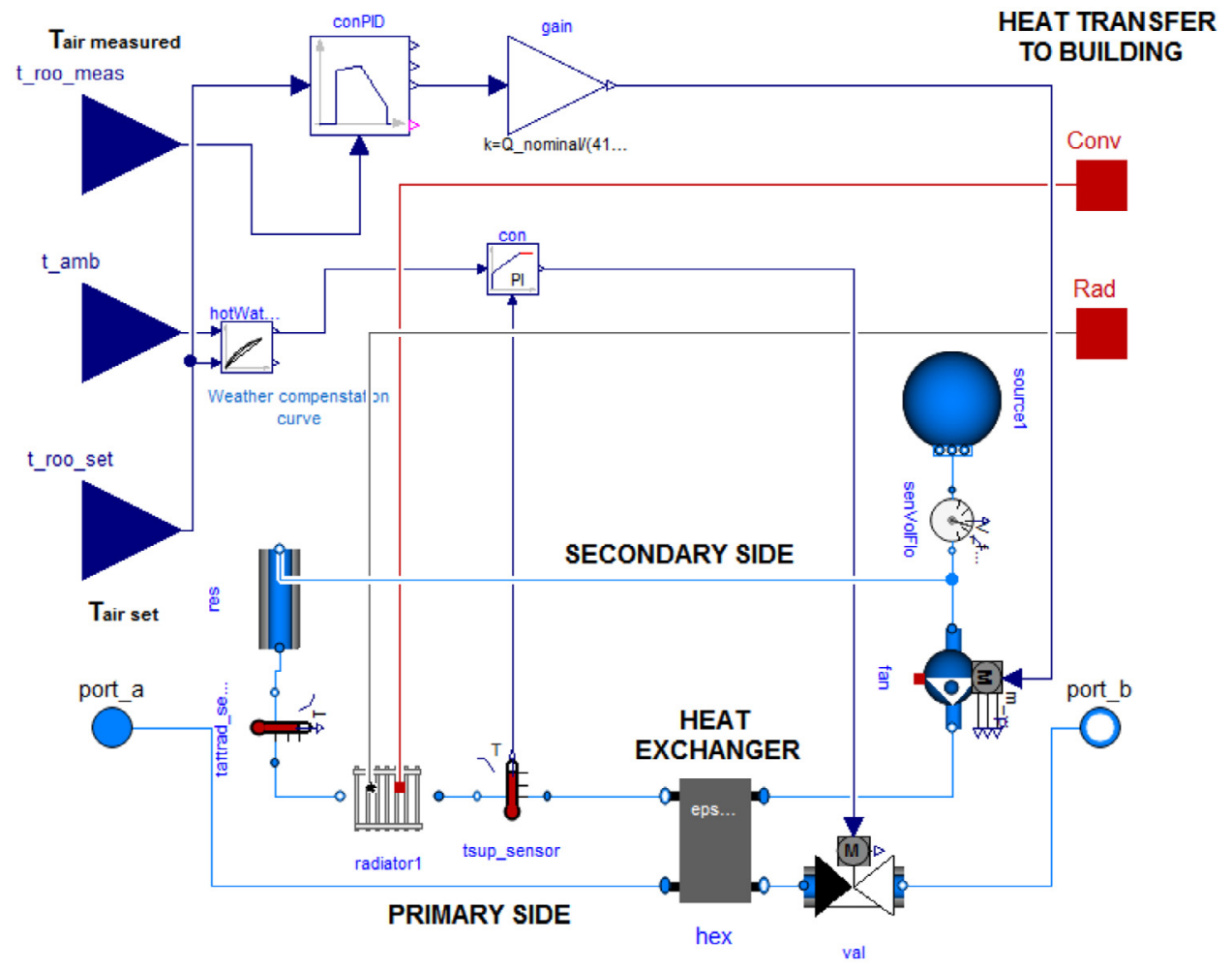

Fig. 2. Schematics of the substation model.

sign temperature difference. The design heat loads of the modelled buildings were based on the results obtained from the TEASER models. It was decided to use these values instead of contracted power of the substations because domestic hot water heat load was not included in the investigation. The indoor temperature was controlled using a PI controller by comparing the indoor temperature with the indoor temperature setpoint. The allowed error was set to $0.25^{\circ} \mathrm{C}$ above or below the setpoint.

The summary of the input parameters is shown in Table 2. The schematic of substation model is shown in Fig. 2.

\subsection{Grid model}

The district heating system analysed in the study is the distribution district heating network supplying the neighbourhood of Nordhavn in Copenhagen, Denmark. The distribution grid is connected to the transmission grid through a heat exchanger. It is a water-based grid, with single supply and single return pipe and district heating substations installed in buildings. The network was designed with $70^{\circ} \mathrm{C}$ as the design temperature. However, currently the system is operated at higher temperature levels, with supply temperatures between $70^{\circ} \mathrm{C}$ and $80^{\circ} \mathrm{C}$ for most of the year. The simplified schematics of the grid investigated can be seen in Fig. 3. The area heat meter (AHM) at the entrance to the area is represented in the schematics with a circle with an arrow. The area heat meter was installed at the entrance to the modelled area to measure the heat supply based on the flow and supply and re-

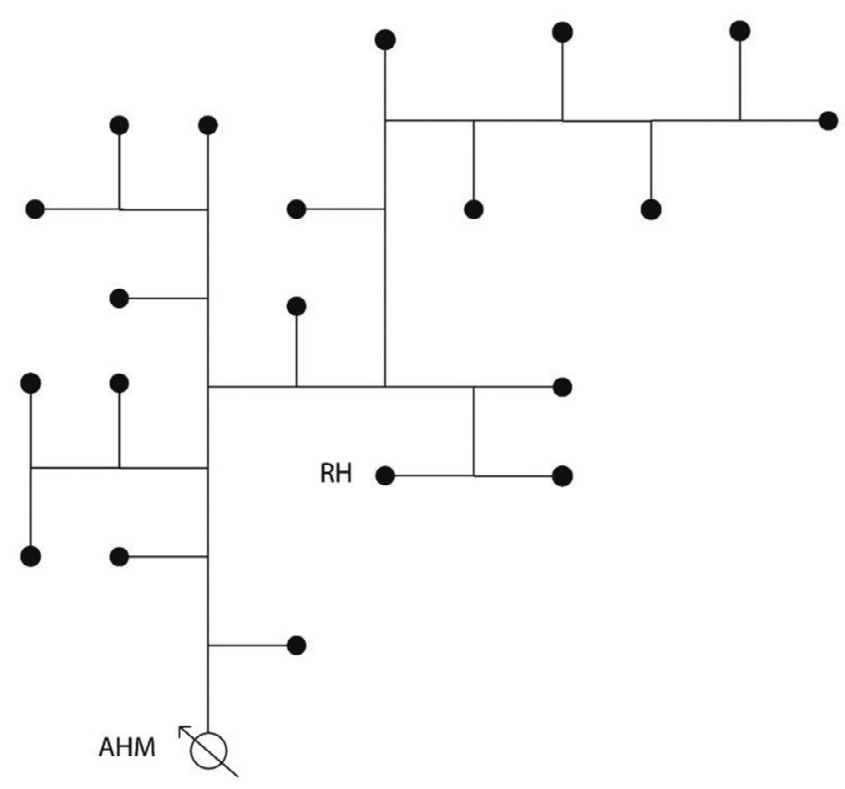

Fig. 3. Schematic of the grid investigated in detail in the case study. AHM - area heat meter, $\mathrm{RH}$ - area with single-family row houses, circles - building substations connected to the grid. 


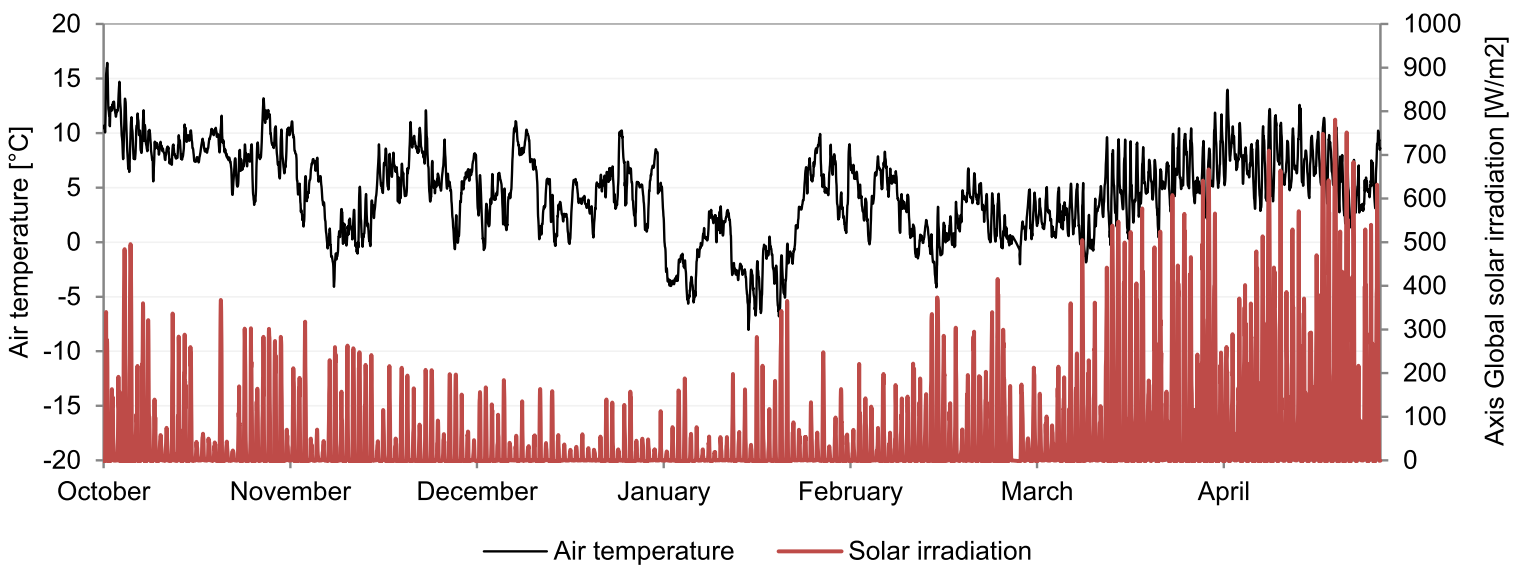

Fig. 4. Ambient air temperature and solar radiation in the simulated period.

turn temperatures in the network, together with supply and return pressures. The building substations connected to the network are represented with circles and the circle described as $\mathrm{RH}$ represents the aggregated heat demand from the row house area. The pipe dimensions and characteristics were based on the existing network used as the case study.

Pipe component used in the grid model comes from the IBPSA library and is described in detail in [33]. The pipe model is a thermo-hydraulic model suitable for representation of thermal network behaviour and includes calculation of heat losses based on input data on pipes' technical characteristics.

\subsection{Heat source}

In reality, the modelled area is a part of larger distribution network connected to the Greater Copenhagen DH network and there is no heat generation or supply pressure control on site. The critical substation in the area is not located in the modelled part of the network.

The heat source for the network was modelled as ideal heater with no set maximum power - it was assumed that the source supplies the heat required by the buildings in the area. The substation furthest away from the entrance to area was considered a critical substation in the modelled area. The pressure difference in this critical substation was set to be kept at 1 bar to reflect that the modelled part of the network operates at higher pressures than the critical area of that distribution network. The circulation pump was controlled to maintain the pressure difference in the critical substation.

\subsection{Boundary conditions}

The weather data used for the simulation were the weather data from the Copenhagen Test Reference Year (TRY) file with the dry bulb ambient temperature substituted with the air temperature measurements from 2016 [11]. It was done to have the weather data matching the period for which the heat production data was available. Ambient air temperature and horizontal solar radiation in the simulated period are shown in Fig. 4.

The ground temperature was assumed to be constant over the simulated periods and to be $8^{\circ} \mathrm{C}$, based on the annual average ground temperature value at ground depth of $0.5 \mathrm{~m}$, as shown in [7]. As mentioned before, the same value was assumed for the ground temperature in contact with building floor slab.

The internal gains were set according to the standard DS/EN ISO 13790:2008, Appendix G.8 [9]. They include both radiative and convective heat gains coming from occupants, lights and equip- ment. The profiles were based on the weekday internal gains pattern. For the residential buildings it was assumed that the ratio between the living room and kitchen area and other conditioned areas is 50:50. The total average heat flow rate from internal gains in residential buildings is $5.8 \mathrm{~W} / \mathrm{m}^{2}$. For the offices, it was assumed that the ratio between the office spaces and other rooms, lobbies and corridors is $60: 40$, as suggested in the standard. The total average heat flow rate from internal gains in office buildings is 7.3 $\mathrm{W} / \mathrm{m}^{2}$. Values of the internal gains per $\mathrm{m}^{2}$ for both residential and office buildings are shown in Table 3.

\subsection{Data from the district heating system}

The district heating system in the Greater Copenhagen area is supplied by prioritised production units ( 3 waste incineration plants, a sewage treatment plant and a geothermal unit), base load units ( 3 CHP plants supported by 2 heat accumulators) and peak and reserve load units (4 large boilers located in the CHP plants and approximately 30 smaller peak load units). The peak and reserve load units are heat-only boilers that run on fossil fuels (mostly natural gas) [35]. Varmelast, a cooperative staffed by employees of 3 district heating companies, is responsible for planning the heat production for the system. The heating plans are prepared based on forecasts disclosed by the district heating companies and take into account fuel prices, operating and maintenance costs, energy taxes on heat production, $\mathrm{CO}_{2}$ quota costs and income from the power market.

The data on heat load and marginal heat production costs in the district heating system of Greater Copenhagen were provided by HOFOR A/S, Greater Copenhagen Utility. The marginal heat production cost is the change in total heat production cost caused by producing one additional heat unit. The marginal cost of heat production does not reflect the price paid by the customers, as the price paid by the customers is set annually and depends on total costs of district heating system operation.

There is a clear seasonal pattern visible in the marginal heat production costs, as can be seen in Fig. 5. This pattern corresponds to the seasonal heat load pattern shown in Fig. 8. The marginal heat costs tend to be the highest in the periods with the highest heat consumption, decreasing in the intermediate season and are the lowest in the summer, when the heat demand is the lowest. This pattern is connected with the types of heat sources supplying heat to the district heating system. Fig. 7 shows an example of marginal heat production costs during a week in February. It can be seen that the price variation is visible not only on a long-term, but also on a short-term basis. Figs. 6 and 9 show, respectively, the averaged weekly profile of the marginal heat production cost and 
Table 3

Values of internal gains during the day in a residential and in an office building [9].

\begin{tabular}{|c|c|c|c|c|}
\hline \multirow[t]{2}{*}{ Hours } & \multicolumn{2}{|l|}{ Residential } & \multicolumn{2}{|l|}{ Offices } \\
\hline & $\begin{array}{l}\text { Living room plus kitchen } \\
{\left[\mathrm{W} / \mathrm{m}^{2}\right]}\end{array}$ & $\begin{array}{l}\text { Other conditioned areas } \\
{\left[\mathrm{W} / \mathrm{m}^{2}\right]}\end{array}$ & $\begin{array}{l}\text { Office spaces ( } 60 \% \text { of } \\
\text { conditioned floor area) }\left[\mathrm{W} / \mathrm{m}^{2}\right]\end{array}$ & $\begin{array}{l}\text { Other rooms, lobbies, corridors } \\
\text { (40\% of conditioned floor area) } \\
{\left[\mathrm{W} / \mathrm{m}^{2}\right]}\end{array}$ \\
\hline $07: 00$ to $17: 00$ & 8.0 & 1.0 & 20.0 & 8.0 \\
\hline $17: 00$ to $23: 00$ & 20.0 & 1.0 & 2.0 & 1.0 \\
\hline $23: 00$ to $07: 00$ & 2.0 & 6.0 & 2.0 & 1.0 \\
\hline
\end{tabular}

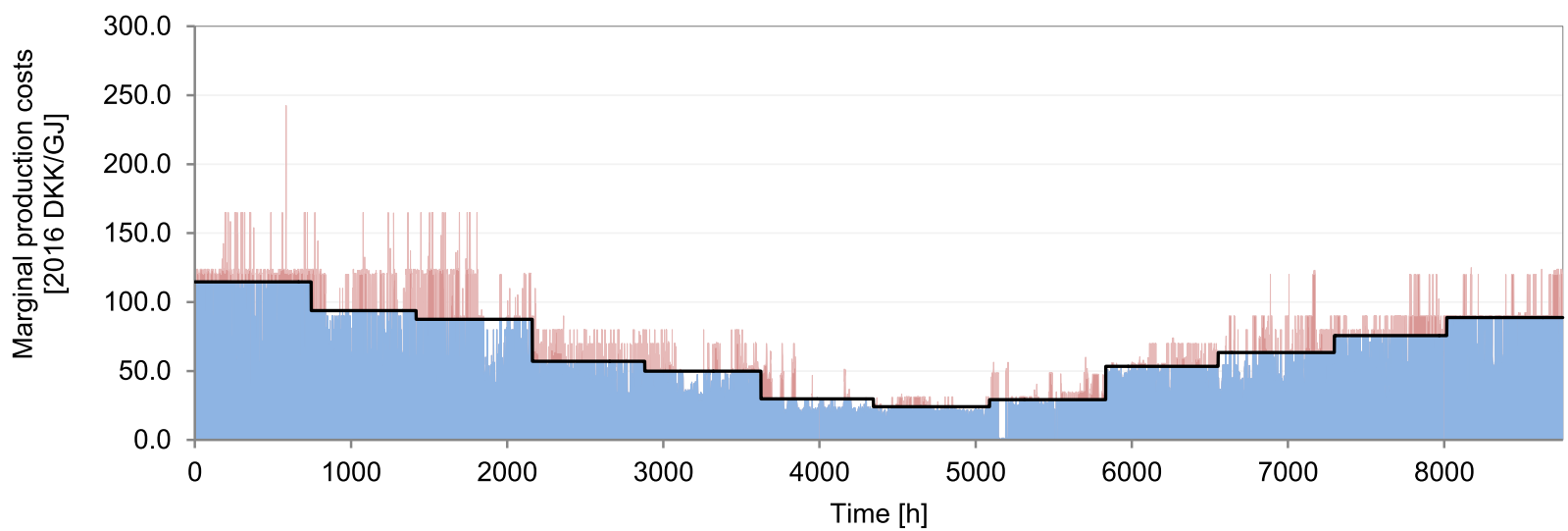

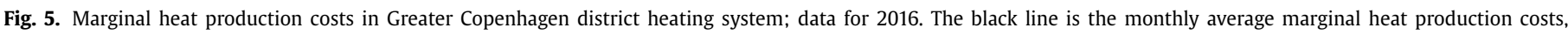

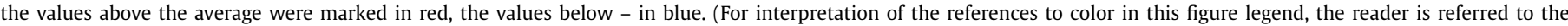
web version of this article.).

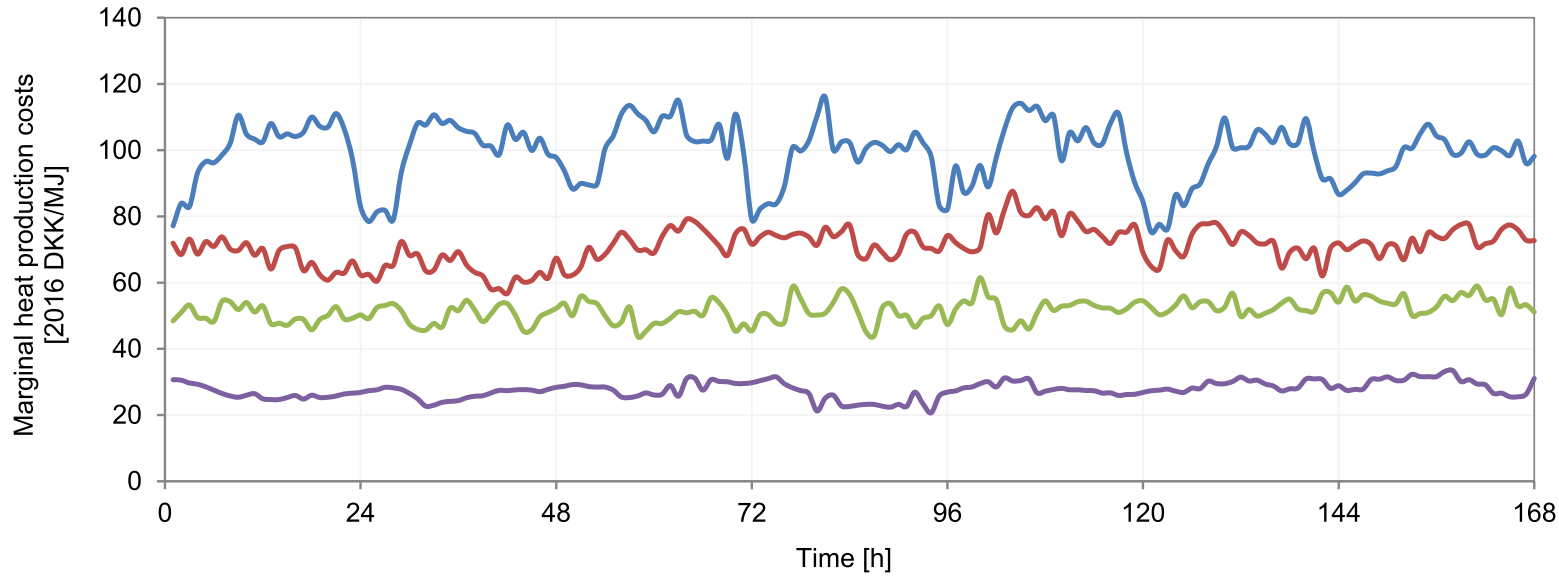

December - February —March - April and October - November — May and September — June - August

Fig. 6. Averaged weekly heat production cost patterns (hourly marginal heat production costs during a week) for different seasons of the year.

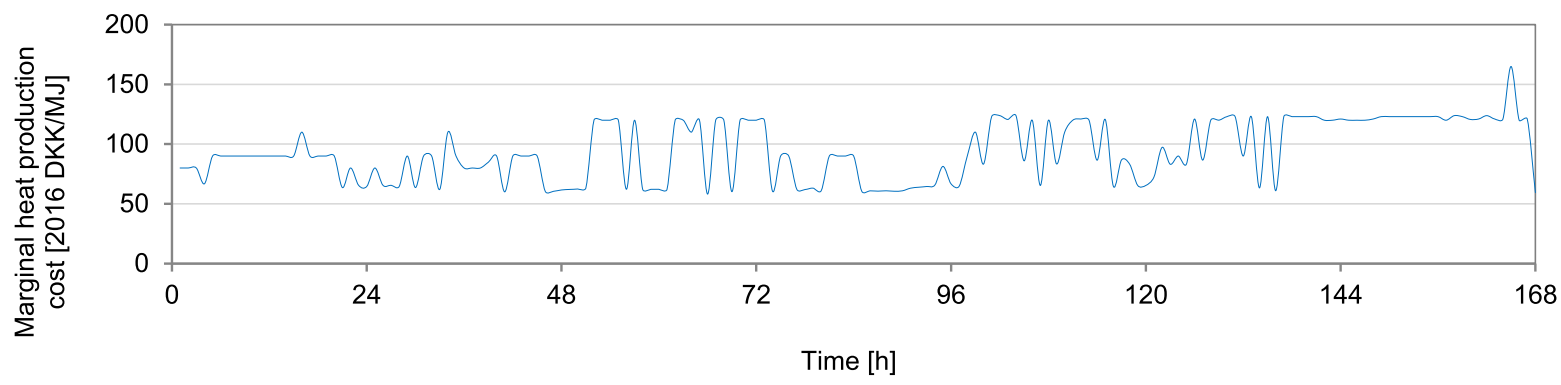

Fig. 7. Marginal heat production costs in Greater Copenhagen district heating system during a single week in February; data for 2016. 


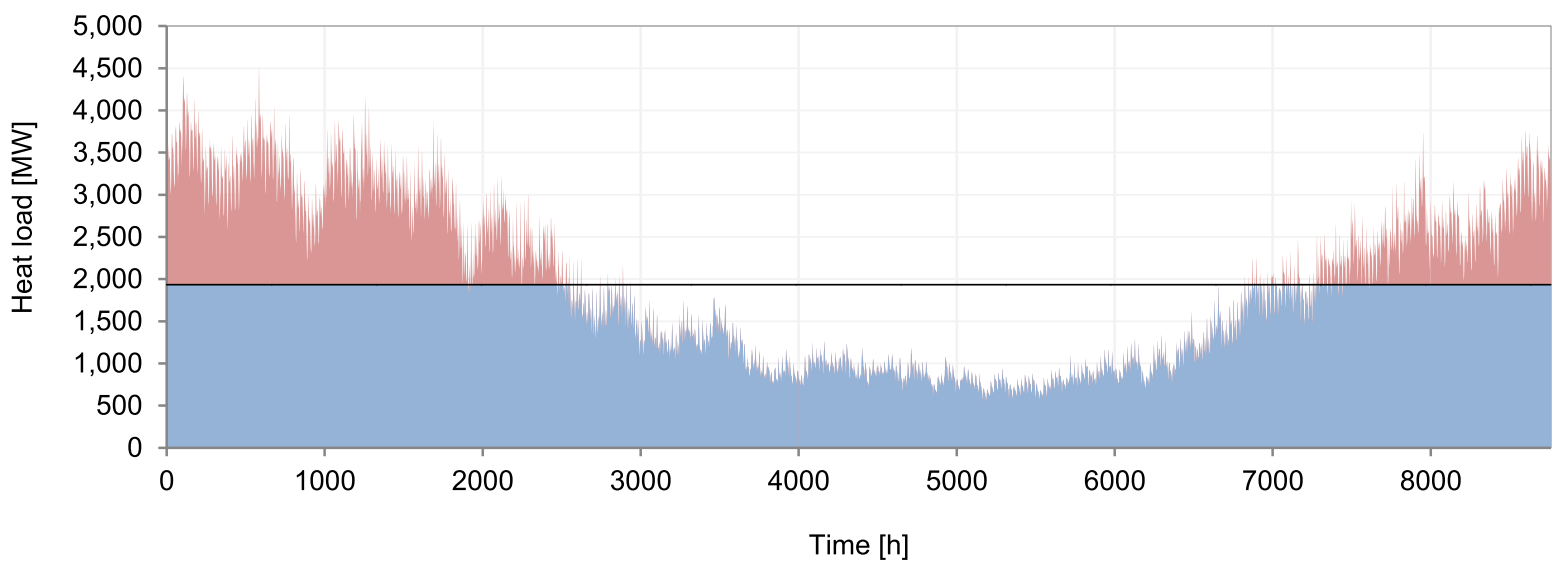

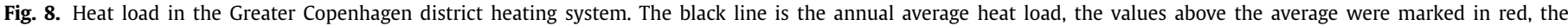
values below - in blue. (For interpretation of the references to color in this figure legend, the reader is referred to the web version of this article.).
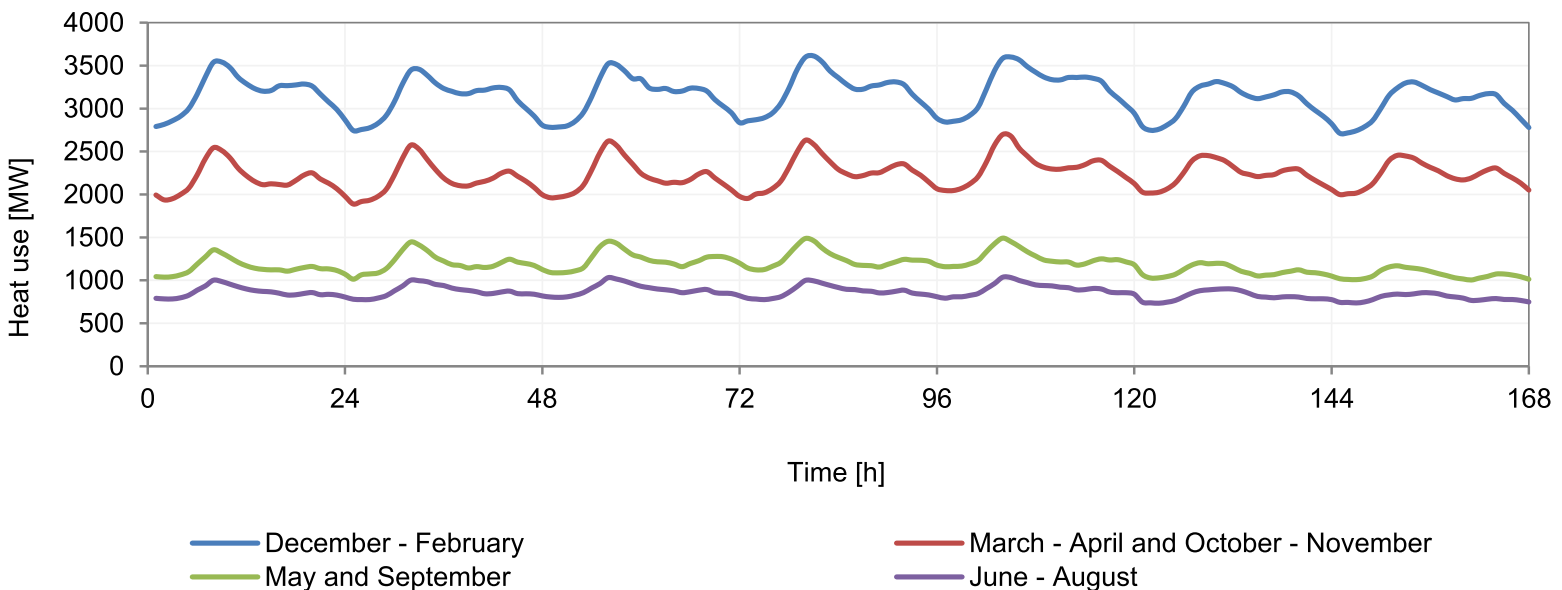

Fig. 9. Heat load variations illustrated using averaged hourly heat load in weekly profiles during a week in different parts of the year.

heat load in different seasons. It can be seen that there is a clear daily pattern in the heat load with two visible peaks, a larger one in the morning and a smaller one in the afternoon, and a decrease in the heat load at night. In the winter period, the profile of heat production costs corresponds to the heat load profile, with higher prices during the day and lower during the night. Such a connection does not seem to exist in other seasons. The lack of visible connection between heat production costs and the heat load profile is, most likely, related to the production units operating. During winter, in the periods of high heat demand, marginal heat production costs are based on heat production costs using expensive heatonly boilers. In the other seasons, the marginal costs are based on heat production costs using units with lower costs, such as CHP plants.

\subsection{Simulations}

In the building sector, the two main approaches to demandside response are direct and indirect load management [17]. Direct load management is based on the direct intervention by the utility. It can be executed and done either at the levels of individual buildings or at the level of a group of buildings. It should be noted that direct load control at the level of the customer is not currently accepted as a solution in the European district heating systems. However, some of the district heating operators are introducing pilot projects based on customer agreements aimed at direct load control. Indirect load control is based on incentives aimed at encouraging customers to utilise demand-side management and adjust the timing of their energy use and its magnitude. Usually such incentives are based on special tariffs to influence customer behaviour. Li, Dane, Finck, \& Zeiler [22] reported that based on the survey results, the respondents in the Netherlands were generally willing to adopt smart technologies and change energy use behaviours, including e.g. reducing the room temperature setpoint.

The possible strategy of load control depends on the level of communication between the building and the heat supplier. If there is no communication platform between the building and the heat supplier, the load control can be executed only based on available knowledge about the system operation and based on pre-set schedules. If there is a communication platform between the building and the heat supplier, the load control can be executed based on the signals from the system. In that way the control scheme can take into account the actual state of the district heating system.

In the case of this study, it was assumed that the indoor temperature setpoint was changed in all apartments in all of the buildings at the same time, what would be more typical for direct load control. However, it could also be assumed that all of the occupants adjusted the temperature setpoint schedules in their apartments thanks to the applied incentives.

The operation of the system was simulated for the period from the 1 st of October to 30th of April. The base scenarios simulated 

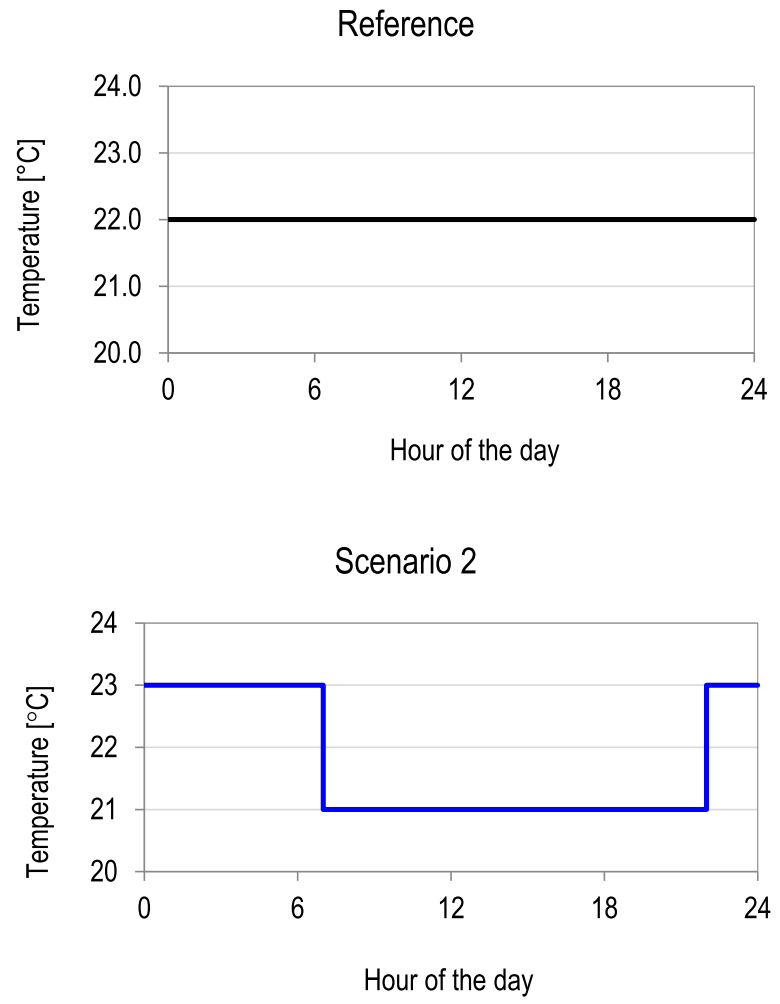
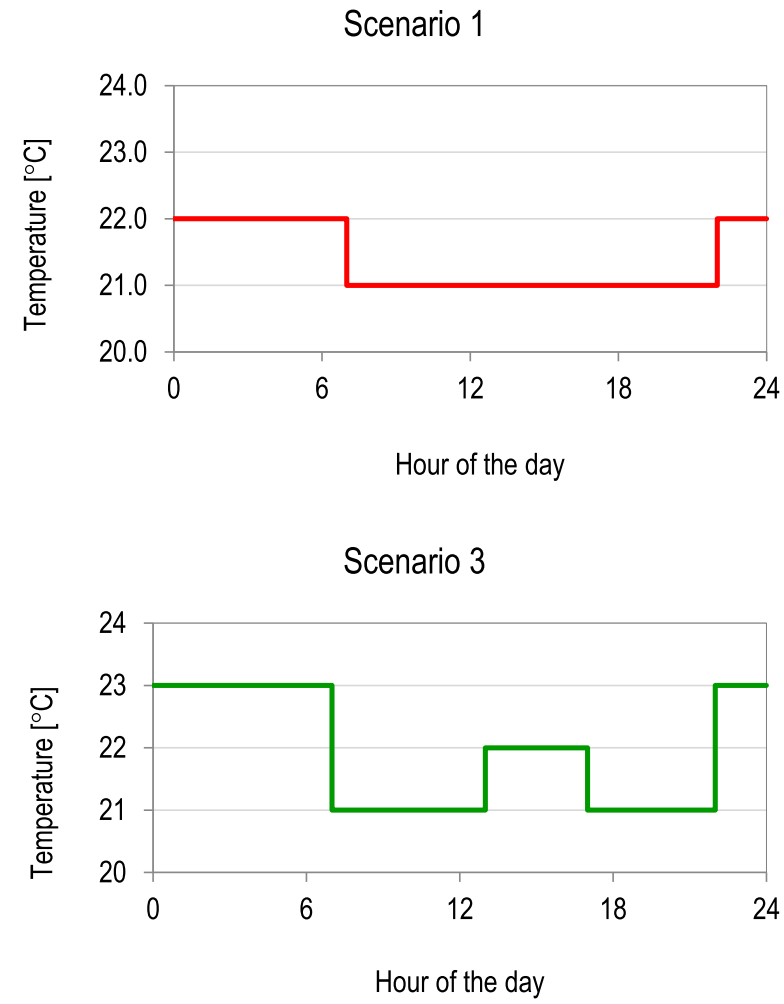

Fig. 10. Temperature setpoint profiles in schedule-based control scenarios with temperature range of $21-23^{\circ} \mathrm{C}$.

were chosen based on the results from [14] and included 3 scenarios with schedule-based setpoint control and 1 scenario with dynamic price-based setpoint control.

The case with constant setpoint of $22^{\circ} \mathrm{C}$ in all of the buildings was used as the reference case.

\subsection{Schedule-based control}

Three of the investigated scenarios are based on pre-set schedules created taking into account usual load pattern in the Greater Copenhagen district heating system. In Scenario 1 the temperature setpoint was lowered by $1^{\circ} \mathrm{C}$ during the day, with the setpoint decrease occurring at $7 \mathrm{a} . \mathrm{m}$. and the setpoint increase at $10 \mathrm{p.m}$. In Scenario 2, a similar pattern was applied, but the temperature setpoint during the night was increased to $23^{\circ} \mathrm{C}$. In Scenario 3 the temperature setpoint was also increased during the night to $23^{\circ} \mathrm{C}$ the same as in Scenario 2, but there was also an additional setpoint change in the middle of the day (from 1 p.m. to 5 p.m.), when the setpoint temperature was increased to $22^{\circ} \mathrm{C}$. The scenarios investigated are aimed at decreasing the morning peak load by using the heat stored in the building in the preceding period. The temperature setpoint schedules for all of the schedule-based scenarios are shown in Fig. 10.

As the initial simulations indicated that implementing the load control strategies resulted in increased peak demand which is generally disadvantageous for the energy system, it was decided to run another simulation for the most promising scenario so far (Scenario 2), with setpoint changes in the different buildings distributed over time to mitigate the increase in peak demand. The new scenario was named "Scenario 2 distr". As the old buildings were shown to cool down quicker and have less thermal capacity, the time of the setpoint increase there was moved 30 min earlier. Simultaneously, the setpoint change in the 5 largest new buildings was moved by 30 mins forward. For the rest of buildings the schedule remained the same as in the initial simulations. The sub- sequent simulation was done using identical setup as in the initial simulations.

\subsection{Dynamic price-based control}

The last investigated scenario is a dynamic scenario with setpoint control based on the marginal heat production costs. As it was mentioned before, such solution would require communication between the energy system and building management system. The temperature setpoint was adjusted based on the signal from the energy system: when the signal value is lower than a low threshold $\left(\mathrm{C}_{\text {low }}\right)$, the temperature setpoint is kept at the increased value $\left(23^{\circ} \mathrm{C}\right)$; when the value of the signal is higher than the high threshold $\left(\mathrm{C}_{\text {high }}\right)$, the setpoint is kept at the low value $\left(21^{\circ} \mathrm{C}\right)$. Between the $C_{\text {low }}$ and $C_{\text {high, }}$ the setpoint is interpolated. In Scenario 4, the $C_{\text {low }}$ value was set at 25 and $C_{\text {high }}$ at 50 percentiles of marginal heat production costs. The temperature setpoint control based on the marginal heat production cost is illustrated in Fig. 11. Dynamic price-based control relying on price signals with hourly resolution will generally results in more setpoint changes per day than the schedule-based setpoint profiles proposed above.

\subsection{Performance evaluation}

The following parameters were used to evaluate the performance of the system in different scenarios. The parameters were based on the work by Foteinaki et al. [14], and calculated using equations listed there. However, in the current paper they were adjusted to refer to the whole investigated network not for an individual building.

1 Total energy delivered to the system for the whole simulated heating season for space heating.

2 Marginal production cost of the energy delivered to the system for space heating. 


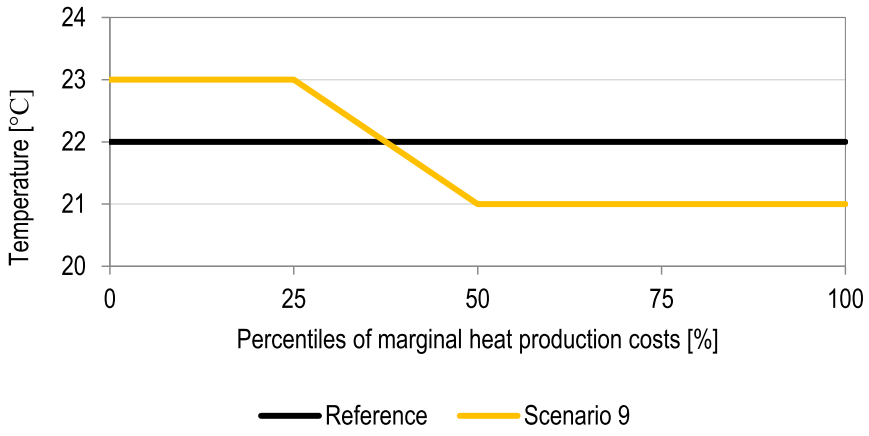

Fig. 11. Temperature setpoint profiles in schedule-based control scenarios.

Table 4

Heating season duration in buildings of different types.

\begin{tabular}{ll}
\hline Building type & Heating season duration [days] \\
\hline Old commercial building & 212 \\
New residential building & 130 \\
New commercial building & 129 \\
\hline
\end{tabular}

3 Peak heating power in the simulated scenario and rebound effect - the highest power peak that occurred after the temperature setpoint returned to the reference settings.

4 The indoor air temperatures in the modelled buildings. Indoor air temperatures were compared as an indicator of thermal comfort, to reflect differences between simulated scenarios.

5 Potential for flexible operation, estimated using two indicators, equivalent to the flexibility indicator defined in [21]:

a $F_{1}$ - indicator of the energy used in the low demand period compared to the energy used on the high demand period. The low demand hours were defined as between 21:00 and 6:00 the following day, based on the district heating daily load variation.

b $F_{2}$ - indicator of total energy use during the low marginal production cost period compared to the energy used on the high marginal production cost. The low production cost hours were defined as the hours, when the marginal production cost was below the monthly median. Correspondingly, the high production cost hours were the hours with marginal production cost above the monthly median.

\section{Results}

The following section presents the simulation results. Section 3.1 looks at the performance of the building models used in the study and the effects different applied scenarios have on buildings. Section 3.2 focuses on the system-level evaluation of individual scenarios.

\subsection{Evaluation of building operation under investigated scenarios}

To gain additional insight on how the applied scenarios impact the buildings in the area the results of the simulation of the building models was analysed.

The results of the initial simulations indicated, that the heating season in the old, poorly insulated buildings is much longer than in the new buildings. The results are summarized in Table 4 that shows heating season duration in the Reference scenario for a representative old commercial building, a representative new residential building and an office building. The heat demand in the old building lasts for the whole investigated period (with short periods in October and April when the heat supply was not needed). In the new residential building the heating season starts in the beginning of November and ends mid-March. In the new office building, it was one day shorter than in the new residential building. The most likely reason for the difference are the greater heat gains in the commercial building.

The different types of buildings in the study were shown to react differently to the temperature setpoint changes. Fig. 12 a-c shows the air temperature in relation to the setpoint temperature for one day in the heating season for different building types included in the model for one day in January. It can be seen that the temperature in the new buildings (both residential and the office building) decreases slower than in the older building. The modelled temperature in the older building fluctuates more significantly than in the new buildings. It is caused by the way the heating system is controlled combined with its large heating power. For all of the buildings, there is a visible impact of the internal heat gains. In case of the old building used for commercial purposes it is indicated by the slower internal temperature decrease between 7 a.m. and 5 p.m. For the new office building (Fig. 12c), it can be seen that the internal gains in that period mitigate the indoor temperature decrease. The drop in air temperature in this figure around 17:00 corresponds to the decrease in internal heat gains in office buildings at that time. The impact of internal heat gains is also visible for the new residential building, where the temperature starts to increase after 5. p.m., when the internal heat gains increase (compare with Table 3 - the increase in heat gains is coming from occupants' activities at home such as e.g. cooking, electronic device use and heat gains from occupants' themselves). The lack of temperature fluctuations in Fig. 12b in the middle of the day is caused by the slow cooling down and the temperature not dropping below the indoor temperature setpoint (taking into account the allowed control error).

The average hourly temperatures during the day in the representative new residential building under all of the main investigated scenarios are shown in Fig. 13. To exclude the impact of shorter heating season in the newer buildings, only the data from the period from December to February was taken into account. For the schedule-based scenarios, there is a clearly visible temperature decrease during the day. As it was also shown for the single day in January in Fig. 12 b, there is also a visible impact of increased internal heat gains starting at 5 p.m. Scenario 4 with dynamic pricebased temperature setpoint has the profile shape closer to the Reference case. However, the indoor air temperature in Scenario 4 was higher than in the Reference scenario by $0.46^{\circ} \mathrm{C}$ on average. This can be explained by the fact that the building retains the heat stored during the periods when the air temperature setpoint is at $23^{\circ} \mathrm{C}$. The difference between these two scenarios is greater during the night-time, as the heat production costs are in general lower during night time, so more of the periods with increased setpoint in Scenario 4 occurred at night-time.

\subsection{System-level evaluation of investigated scenarios}

Fig. 14 presents the first 3000 hours of the load duration curves for the initially investigated 5 scenarios. All of the investigated load shifting scenarios resulted in a higher peak demand than the Reference case and in a steeper shape of the load duration curve with more high-load hours and fewer lower load hours, compared to the Reference scenario. As expected, the peak increase is the smallest in Scenario 1, where the temperature setpoint was only lowered. However, compared to the findings from [14], also the scenario where the temperature setpoint was only decreased resulted in a peak heat demand increase. This is related to the fact that the heating systems in majority of the buildings switch on at the same time. Scenarios with heating setpoint both decreased and increased resulted in peak higher than in case of the scenario with only setpoint decrease. The simulated peaks are still within the capacity of the local district heating network and there still is a remaining 

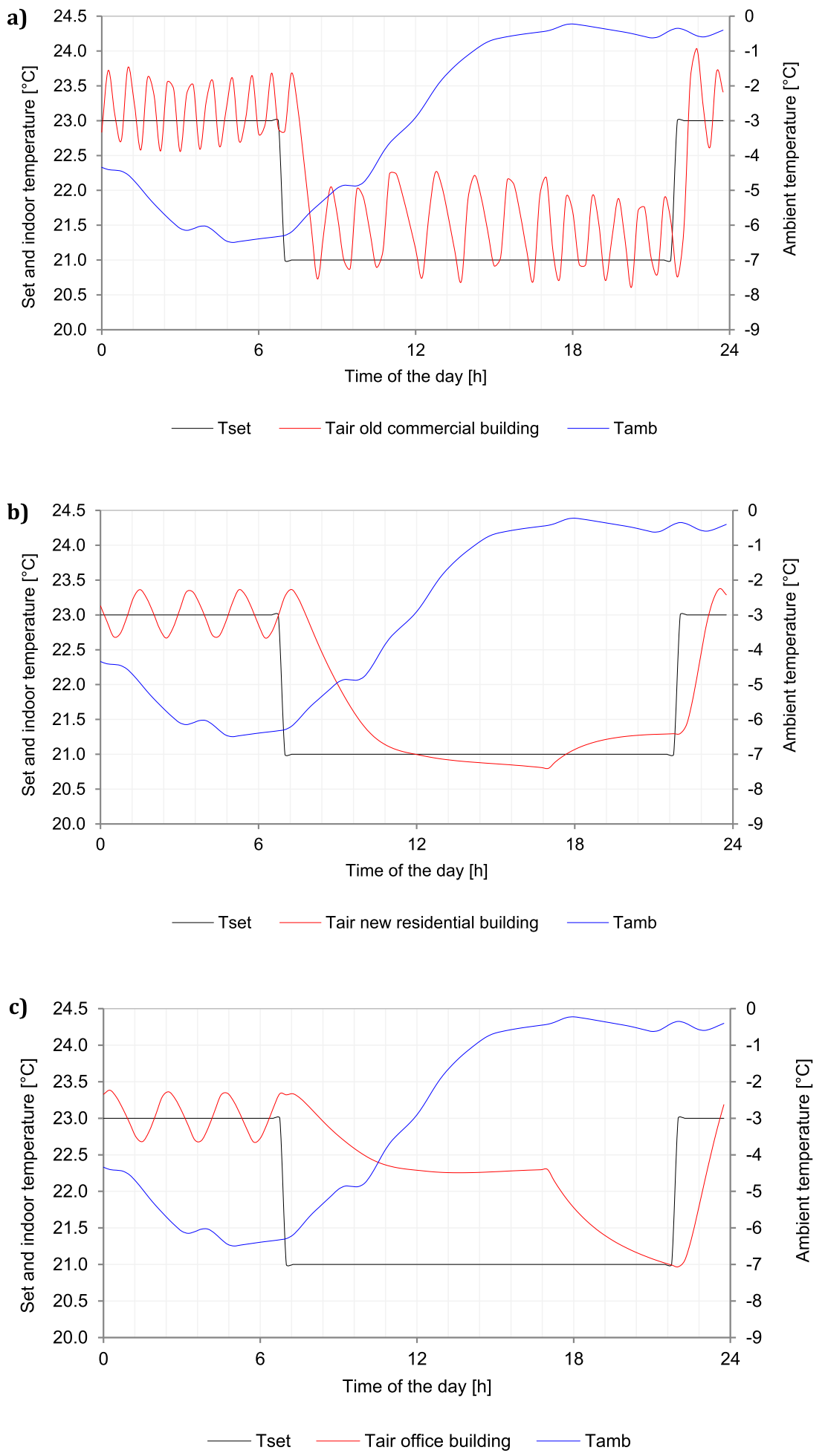

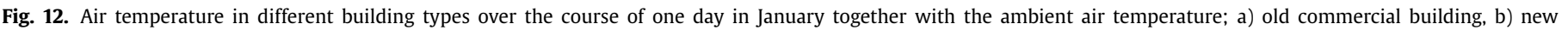
residential building, c) new office building.

capacity for domestic hot water preparation. Usually, the increased peak demand is not considered beneficial for the system operation. Additionally, higher peak demand results possibly in the need for higher installed system capacity. However, in case the investment in the additional capacity can be avoided, in the CHP-based systems the increased heat demand coinciding with high electricity prices can be advantageous from the business perspective
Another important factor in evaluating the investigated scenarios is the daily distribution of the heat load (Fig. 15). The Reference case is characterized by the flattest shape of the averaged heating load of all the investigated scenarios. The decrease in the heat load that is visible also in the Reference scenario is caused by the fact that the investigated model includes space heating only and there the solar heat gains during the day cover part of the heat demand. This is most visible in the late afternoon and evening and is caused 


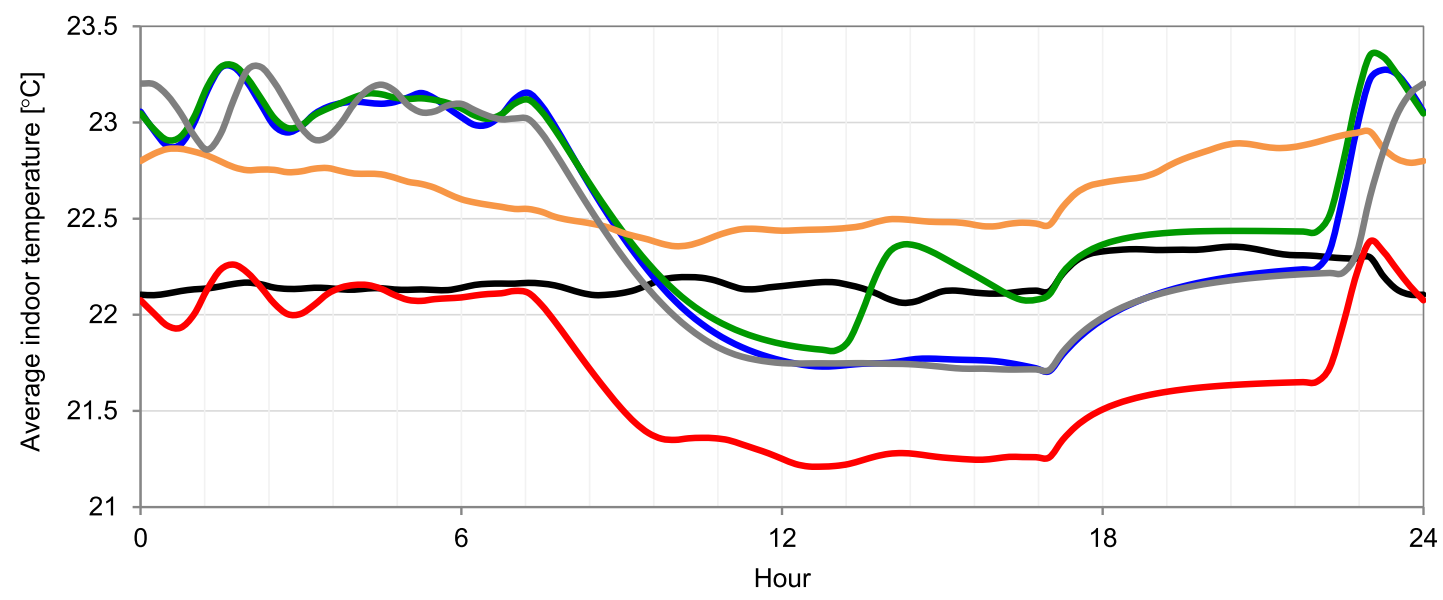

Reference $\longrightarrow$ Scenario $1 \longrightarrow$ Scenario $2 \longrightarrow$ Scenario $3 \longrightarrow$ Scenario $4 \longrightarrow$ distr

Fig. 13. Average air temperature in the representative new residential building during a day in the period from December to February.
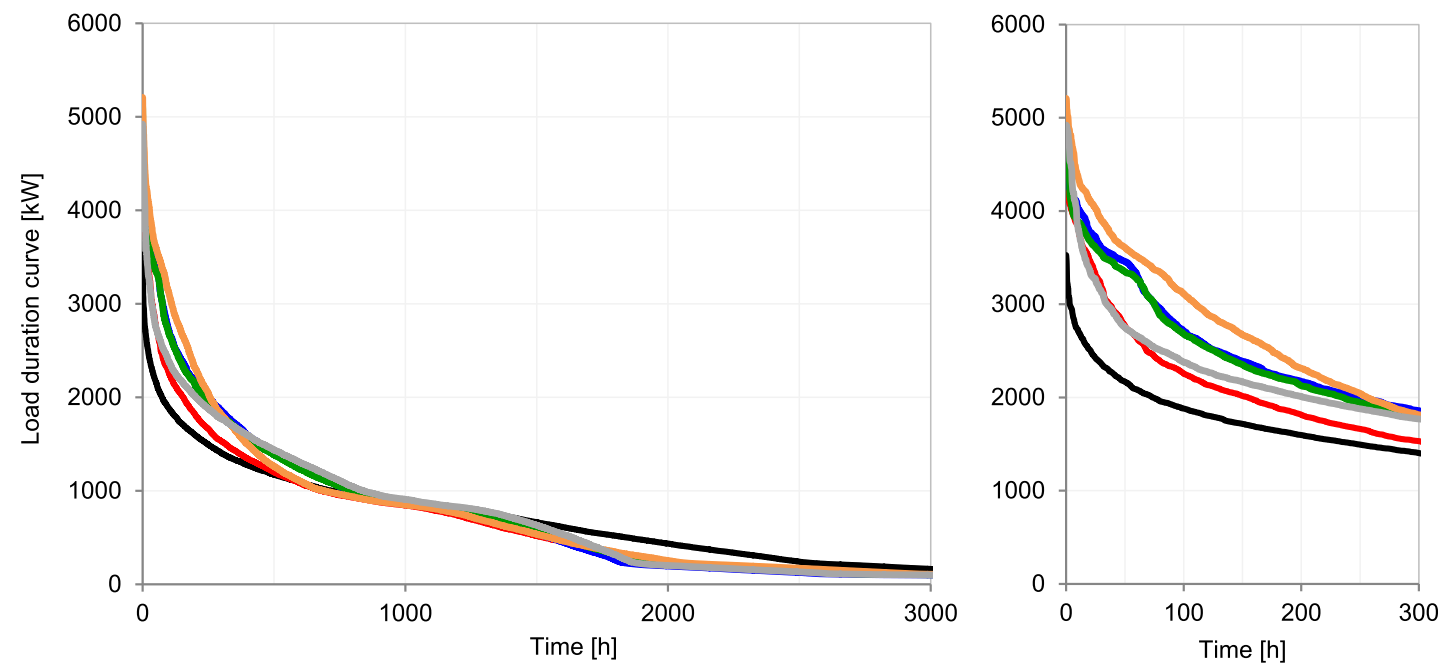

Reference Scenario 1

Scenario 2

Scenario 3

Scenario 4

Scenario 2 distributed

Fig. 14. First 3000 hours of the load duration curves for different scenarios together with the zoomed in plot for the first 300 hours.

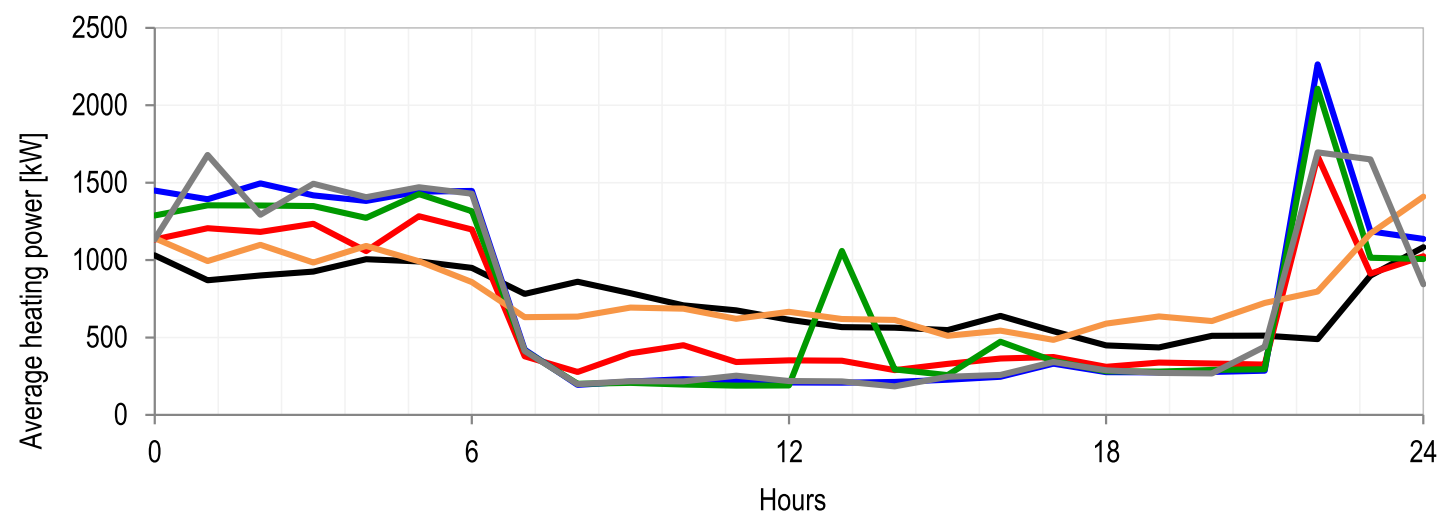

Reference Scenario Scenario 2 Scenario 3

Scenario $4 \longrightarrow$ Scenario 2 dist

Fig. 15. Averaged hourly heat load in the investigated system from the beginning of December to the end of February. 
Table 5

Summary of the key indicators used for scenario evaluation.

\begin{tabular}{llllllll}
\hline \multirow{2}{*}{ Scenarios } & \multicolumn{5}{c}{ Difference from reference scenario } & \\
\cline { 2 - 6 } & Total energy [\%] & Costs [\%] & Average temperature $\left[{ }^{\circ} \mathrm{C}\right]$ & Energy use in the morning [\%] & Rebound effect [\%] & F1 & F2 \\
\hline Reference & - & - & - & - & - & $35 \%$ & 0.05 \\
Scenario 1 & $-6.6 \%$ & $-9.0 \%$ & -0.53 & $-41 \%$ & 0.20 \\
Scenario 2 & $2.0 \%$ & $-2.5 \%$ & 0.19 & $-51 \%$ & $49 \%$ & 0.27 \\
Scenario 3 & $2.9 \%$ & $-0.8 \%$ & 0.37 & $-49 \%$ & $47 \%$ & 0.17 \\
Scenario 4 & $4.2 \%$ & $-1.8 \%$ & 0.48 & $18 \%$ & $48 \%$ & 0.21 \\
Scenario 2 distr & $2.0 \%$ & $-2.4 \%$ & 0.15 & $-46 \%$ & $40 \%$ & 0.38 & 0.21 \\
\hline
\end{tabular}

by the profile of the internal heat gains used as input for the residential building model. As most of the buildings in area are residential buildings, their characteristics affect the aggregated heat demand the most. The decreased temperature setpoint during the day in the schedule-based scenarios results in a further demand decrease during the day. The schedule-based scenarios achieve the goal of shifting the load to the low-load period. However, it comes at the cost of an increased heat demand at the time of the setpoint increase in the evening. The decrease is more significant for the scenarios with increased temperature setpoint during the nighttime. It can be seen, that the Scenario 4 shape of the daily averaged heat load is similar to the Reference daily averaged heat load. However, the heat load decrease in the afternoon that occurs for the Reference case does not occur for Scenario 4. Instead, the heat demand during night-time is higher than for the Reference case, but the heat demand in the morning is lower (ca. 27\% difference at 8 a.m.).

The main results of the study, including the flexibility indicators $F_{1}$ and $F_{2}$, are summarized in Table 5 . It can be seen that the values of indicator $F_{1}$ clearly improved for all of the schedule-based scenarios, compared to the Reference case. Scenario 2 is characterized by the highest value of indicator $F_{1}$. This is a scenario with pre-heating during the night time and a constant decreased temperature setpoint during the day. Indicator $\mathrm{F}_{2}$ for Scenario 1 decreased slightly compared to the Reference case (0.17 compared to 0.20 ) and increased minimally for Scenario 2 and 3 (0.21 compared to 0.20 ). Dynamic price-based Scenario 4 is characterized by the highest value of indicator $F_{2}$ of 0.39 . However, the $F_{1}$ indicator for this scenario decreased slightly compared to the Reference case (nearly the same amounts of energy were used in the high-load period as in the low-load period). Modified Scenario 2 with distributed setpoint increase performed, in regard to F1 and F2 indicators, nearly identically to initial Scenario 2 . Based on the results presented in Table 5 it can be seen that each of the proposed scenarios resulted in an improvement in at least some of the chosen indicators. However, none of the scenarios performed clearly better than the other ones in all of the categories. Scenario 1 resulted in the highest energy and cost savings, 6.6\% and 9.0\% respectively. However, the average indoor air temperature in the control building in that scenario was by $0.53^{\circ} \mathrm{C}$ lower than in the reference scenario. Scenario 2 and Scenario 3 performed relatively similarly regarding the decrease in energy use in the morning, increase in peak demand power and $\mathrm{F}_{1}$ and $\mathrm{F}_{2}$ flexibility indicators. However, Scenario 2 resulted in greater cost savings than Scenario $3(2.5 \%$ compared to $0.8 \%$ ) and lower total energy use, that was related to the lower average air temperature. Scenario 4 resulted in the best $\mathrm{F}_{2}$ indicator. However, it was also characterized by the greatest increase in energy use compared to the Reference case an increase in energy use in the morning. The last of the investigated scenarios, Scenario 2 with distributed setpoint increase as expected performed similarly to Scenario 2 . However, the peak power demand increase was reduced from $49 \%$ to $40 \%$. For each of the schedulebased scenarios, the highest peak demand was registered before the time of the setpoint change.

\section{Discussion}

The results of the study show a significant potential for the buildings to be used as thermal energy storage for the district heating system. All of the implemented load scenarios resulted in load shifting on the level of the investigated district heating network area. However, the choice of the optimal scenario is a decision based on several factors and should be influenced by the characteristics of the district heating system in question. In case of the price-based strategies, such as Scenario 4, one of the methods to limit their negative impact would be optimizing the indoor temperature setpoint profile while limiting the number of setpoint changes that can occur during the day and setting a minimal duration of the setpoint.

The results of the investigation are heavily dependent on the performance and accuracy of the building model. In the proposed model the internal and solar gains are used more efficiently than they would be used in a real building. This is because the building was modelled as a single zone with perfect mixing and uniform air temperature distribution. In real buildings the solar gains would not be distributed evenly in the whole building. Moreover, the solar radiation would not reach the interior of all of the rooms at all times during the day, as the rooms would have generally windows only with one or two orientations. This would generally result in greater and more evenly distributed space heating $(\mathrm{SH})$ demand in the modelled buildings. Additionally, all of the buildings modelled were assumed to have square floor plan with windows evenly distributed among the four external walls. This resulted in a more homogenous thermal behaviour of buildings than what would take place in reality. Domestic hot water (DHW) was not included in the investigation. It is typically DHW preparation that causes the morning and afternoon peak in heat demand. Because only SH was included in the study, also the Reference case was characterized by decreased heat use during the day caused by solar heat gains. The observed periods when heating could be cut off in the new buildings were shorter than in [12], where a more detailed simulation model was used.

The results indicate the importance of proper control of demand-side management strategies if they are to benefit the district heating system without causing additional potential difficulties in its operation by increasing the peak energy demand. On the other hand, it can be argued that the increase in energy use during the low-load period or, particularly, in periods with particularly low energy prices should not be problematic for the system. As the low energy prices in systems with high share of renewable energy sources often correspond to the periods with high availability of energy generated from such energy sources, this increase should not result in increased $\mathrm{CO}_{2}$ emissions. Moreover, in the case of the systems supplied with the CHP plants peak heat demand that occurs during a period of high electricity prices can be beneficial for the utility company, as it can allow for profiting from increased electricity production. The control strategies discussed in the paper focused on the needs of the district heating system and its optimal operation, not on the customers' profit. The actual payment 
scheme for the customers in the Greater Copenhagen district heating system includes the payment for contracted power, heat used and a price adjustment based on the return temperature from the substation (on the network side) [16].

Despite the promising results of using building mass as thermal energy storage for the district heating system (or integrated energy system), implementation of this solution widely in practice remains problematic. In case of the study performed, the challenge in the practical implementation is the way the district heating substations and heating systems in the buildings are controlled. In the current setup, if the decreased or increased heat supply is introduced only on the system level, the heating system of a building will try to compensate. In case of new and active thermostatic valves counteracting the charge and discharge of the heat storage, the change in indoor temperature will be limited to the dead zone of the thermostatic valves [27]. This effect was mentioned in [2], where the initial attempt to implement load shifting through the control of secondary side supply temperature was unsuccessful due to secondary control in the buildings. In the current study it was assumed that the building indoor temperature setpoint is controlled according to either pre-set schedule or a signal from the district heating system. The strategy implemented in the current study is in fact more typical for the direct than indirect load control and could be implemented by controlling the building management system. However, district heating operators do not have a possibility to influence the operation of the building management systems. A method that is easier to implement in current conditions is control of the supply temperature on the secondary side of the substation - this method was used e.g. in the study by Kärkkäinen et al. [17].

It should be considered, what types of buildings should be included in the load shifting strategies. Based on the results of the current study, well insulated buildings with large thermal mass are the most suitable for the strategies including preheating combined with interrupted heat supply. In poorly insulated buildings with smaller thermal mass increased temperature setpoint leads to greater heat losses (and consequently heat use) and the amount of heat stored is able to cover the demand for much shorter time. On the other hand, buildings with small thermal mass were determined to be the most suitable for load shifting aimed at limiting the impact of night set-back [3].

The results of the study for the investigated area are slightly less promising than in the investigation for the single new residential building presented in [14], as both the load shifting in the morning and cost savings were shown to be smaller. This is connected both to the fact that there are also older buildings with lower thermal capacity connected to the network and to the fact that in the current study the building heating system was not modelled in detail and the thermal capacity of the heating system itself was then underestimated. However, even after taking into account these differences, the flexibility potential of heat storage in the buildings' thermal mass to support the district heating system operation is still significant.

\section{Conclusions}

The current paper investigated the potential of a small district with buildings connected to a district heating network for a flexible operation according to the needs of the district heating system. The investigation focused on space heating demand and used buildings' thermal mass as the thermal energy storage. The activation of the thermal mass was achieved by changing the indoor temperature setpoint. Based on the shape of the demand curve in the Greater Copenhagen district heating system and the marginal heat production costs, it was generally considered beneficial for the system to shift the energy use to the night-time and decrease the energy use during the day, especially in the mornings. The implemented control strategies were chosen to reflect that. The results indicate that there is a significant potential for flexible operation of buildings connected to the district heating systems and for the building thermal mass to be utilized as short-term thermal energy storage. The proposed strategies have shown to be effective at load shifting - in particular, all of the schedule based scenarios resulted in the energy use in the morning decreased by $41 \%$ to $51 \%$, as compared to the reference case. All of the applied strategies with pre-heating resulted in increased total energy use (by $2.0 \%$ to $4.2 \%$ ). Still, despite of this increase, the total costs in all of the investigated cases were lower than in the Reference case (decrease by $0.8 \%$ to $2.5 \%$ ). The scenario where the pre-heating was not applied resulted in a decrease of both total energy use and total costs (by $6.6 \%$ and $9.0 \%$, respectively). All of the applied scenarios resulted in an increase in peak heat demand (by 35\% up to $49 \%$ ). However, it was also shown that distributing the setpoint increase can partially mitigate the peak demand increase. After distributing the setpoint change over time in Scenario 2, the peak increased by $49 \%$ to $40 \%$, without decreasing other performance indicators. The choice of the best performing scenario requires an analysis of multiple factors and taking into account the characteristics of the district heating system in question, substation equipment in the connected buildings and users' acceptability of proposed strategies. All of these factors require further analysis in the context of implementing the load-shifting in the district heating systems. Moreover, the exact strategies of mitigating the peak demand increase as a consequence of the demand response should be investigated further, preferably including also tests in the real systems.

\section{Declaration of Competing Interest}

The authors declare that they have no known competing financial interests or personal relationships that could have appeared to influence the work reported in this paper.

\section{CRediT authorship contribution statement}

Katarzyna M. Luc: Methodology, Software, Validation, Visualization, Writing - original draft. Rongling Li: Conceptualization, Writing - review \& editing. Luyi Xu: Methodology, Software. Toke R. Nielsen: Supervision, Writing - review \& editing, Project administration. Jan L.M. Hensen: Conceptualization, Supervision.

\section{Acknowledgment}

This research project is funded by Danish EUDP (Energy Technology Development and Demonstration Program); project title: EnergyLab Nordhavn - New Urban Energy Infrastructure, project numbers: 64014-0555 and 64015-0555. Moreover, the authors would also like to thank HOFOR - Greater Copenhagen Utility for providing the data and answering our questions regarding network operation. I would also like to sincerely thank Tatiana Gabderakhmanova with whom I've initially worked on this project.

\section{Supplementary materials}

Supplementary material associated with this article can be found, in the online version, at doi:10.1016/j.enbuild.2020.110074.

\section{References}

[1] D. Basciotti, F. Judex, O. Pol, R.-R. Schmidt, Sensible heat storage in district heating networks : a novel control strategy using the network as storage, in: Conference Proceedings of the 6th International Renewable Energy Storage Conference IRES, 2011. 
[2] D. Basciotti, R.-R. Schmidt, Demand side management in district heating networks: Simulation case study on load shifting, Euroheat Power 2013 (2013) 43-46 10 IV.

[3] D. Basciotti, R.-R. Schmidt, Peak reduction in district heating networks: a comparison study and practical considerations, 14th International Symposium on District Heating and Cooling, 2014.

[4] K. Bruninx, D. Patteeuw, E. Delarue, L. Helsen, W. D'haeseleer, Short-term demand response of flexible electric heating systems: the need for integrated simulations, in: 2013 10th International Conference on the European Energy Market (EEM), 2013, pp. 1-10. https://doi.org/10.1109/EEM.2013.6607333.

[5] H. Cai, C. Ziras, S. You, R. Li, K. Honoré, H.W. Bindner, Demand side management in urban district heating networks, Appl. Energy 230 (August) (2018) 506-518. https://doi.org/10.1016/j.apenergy.2018.08.105.

[6] X. Chen, C. Kang, M. O'Malley, Q. Xia, J. Bai, C. Liu, H. Li, Increasing the flexibility of combined heat and power for wind power integration in China: modeling and implications, IEEE Trans. Power Syst. 30 (4) (2015) 1848-1857. https://doi.org/10.1109/TPWRS.2014.2356723.

[7] A. Dalla Rosa, H. Li, S. Svendsen, Method for optimal design of pipes for lowenergy district heating, with focus on heat losses, Energy 36 (5) (2011) 24072418. https://doi.org/10.1016/j.energy.2011.01.024.

[8] Danish Energy Agency. (2015). Regulation and planning of district heating in Denmark. Retrieved from http://www.ens.dk/sites/ens.dk/files/climate-co2/ Global-Cooperation/Publications/Publications/regulation_and_planning_of_ district heating in_denmark.pdf.

[9] Dansk Standard. (2008). DS/EN ISO 13790. Bygningers energieffektivitet Beregning af energiforbrug til rumopvarmning og -køling. Energy performance of buildings - Calculation of energy use for space heating and cooling ( 2 . udgave).

[10] Dassault Systèmes, Dymola, Dynamic Modeling Laboratory, 2018.

[11] Department of Civil Engineering; Technical University of Denmark. (n.d.). DTU Climate Station. Retrieved from http://climatestationdata.byg.dtu.dk.

[12] K. Foteinaki, A. Heller, C. Rode, Modeling energy flexibility of low energy buildings utilizing thermal mass, 9th International Conference on Indoor Air Quality Ventilation \& Energy Conservation In Buildings (IAQVEC), 2016.

[13] K. Foteinaki, R. Li, A. Heller, C. Rode, Heating system energy flexibility of lowenergy residential buildings, Energy Build. 180 (2018) 95-108. https://doi.org/ 10.1016/j.enbuild.2018.09.030.

[14] K. Foteinaki, R. Li, C. Rode, J. Salom, Evaluation of energy flexibility of lowenergy residential buildings connected to district heating, Energy Build. (2020). https://doi.org/10.1016/j.enbuild.2020.109804.

[15] H. Gadd, S. Werner, Daily heat load variations in Swedish district heating systems, Appl. Energy 106 (2013) 47-55. https://doi.org/10.1016/j.apenergy.2013. 01.030

[16] HOFOR A/S. (2020). Prisen på fjernvarme 2020 for privatkunder. Retrieved February 1, 2020, from https://www.hofor.dk/privat/priser-paa-forsyningerprivatkunder/prisen-paa-fjernvarme-2020-privatkunder/.

[17] S. Kärkkäinen, K. Sipilä, L. Pirvola, J. Esterinen, E. Eriksson, S. Soikkeli, C. Eisgruber, Demand side management of the district heating systems. VTT Research Notes (Vol. 2247), Espoo (2003). Retrieved from http://www.vtt.fi/inf/ pdf/tiedotteet/2004/T2247.pdf.

[18] H. Kauko, K.H. Kvalsvik, D. Rohde, N. Nord, Å. Utne, Dynamic modeling of local district heating grids with prosumers: a case study for Norway, Energy 151 (2018) 261-271. https://doi.org/10.1016/j.energy.2018.03.033.

[19] J. Kensby, A. Trüschel, J.-O. Dalenbäck, Potential of residential buildings as thermal energy storage in district heating systems - results from a pilot test, Appl. Energy 137 (2015) 773-781. https://doi.org/10.1016/j.apenergy.2014.07.026.

[20] J. Kiviluoma, P. Meibom, Flexibility from district heating to decrease wind power integration costs, in: Proceedings of The 12th International Symposium on District Heating and Cooling, Tallin, 2010.
[21] J. Le Dréau, P. Heiselberg, Energy flexibility of residential buildings using short term heat storage in the thermal mass, Energy 111 (1) (2016) 1-5. https://doi. org/10.1016/j.energy.2016.05.076.

[22] R. Li, G. Dane, C. Finck, W. Zeiler, Are building users prepared for energy flexible buildings?-A large-scale survey in the Netherlands, Appl. Energy 203 (2017) 623-634. https://doi.org/10.1016/j.apenergy.2017.06.067.

[23] G. Masy, E. Georges, C. Verhelst, V. Lemort, P. André, Smart grid energy flexible buildings through the use of heat pumps and building thermal mass as energy storage in the Belgian context, Sci. Technol. Built Environ. 21 (6 (October)) (2015) 800-811. https://doi.org/10.1080/23744731.2015.1035590.

[24] Modelica Association, Modelica ${ }^{\circledR}$ - A Unified Object-Oriented Language for Systems Modeling, Language Specification (2012). Version 3.3 https://doi.org/ 10.1016/j.psfr.2003.11.003.

[25] M. Münster, P.E. Morthorst, H.V. Larsen, L. Bregnbæk, J. Werling, H.H. Lindboe, $\mathrm{H}$. Ravn, The role of district heating in the future Danish energy system, Energy 48 (1) (2012) 47-55. https://doi.org/10.1016/j.energy.2012.06.011.

[26] T.S. Nouidui, K. Phalak, W. Zuo, M. Wetter, Validation and application of the room model of the modelica buildings library, Presented at the 9th International Modelica Conference, September 2012, Ernest Orlando Lawrence Berkeley National Laboratory, 2012.

[27] L.C. Olsson Ingvarson, S. Werner, Building mass used as short term heat storage, In 11th International Symposium on District Heating and Cooling, August 31 - September 2, 20082008.

28] P. Remmen, M. Lauster, M. Mans, M. Fuchs, T. Osterhage, D. Müller, TEASER: an open tool for urban energy modelling of building stocks, J. Build. Perform. Simul. 11 (1) (2018) 84-98. https://doi.org/10.1080/19401493.2017.1283539.

[29] K. Schaber, F. Steinke, T. Hamacher, Managing temporary oversupply from renewables efficiently: electricity storage versus energy sector coupling in Germany, Int. Energy Workshop 2013 (2013) 1-22.

[30] TABULA Web Tool. (n.d.). Retrieved from http://webtool.building-typology.eu.

[31] The Danish Ministry of Economic and Business Affairs, Danish Enterprise and Construction Authority, Danish Building Regulations (2015) BR15.

[32] M. Turski, R. Sekret, Buildings and a district heating network as thermal energy storages in the district heating system, Energy Build. 179 (2018) 49-56. https: //doi.org/10.1016/j.enbuild.2018.09.015.

[33] B. van der Heijde, M. Fuchs, C. Ribas Tugores, G. Schweiger, K. Sartor, D. Basciotti, L. Helsen, Dynamic equation-based thermo-hydraulic pipe model for district heating and cooling systems, Energy Convers. Manag. 151 (August) (2017) 158-169. https://doi.org/10.1016/j.enconman.2017.08.072.

[34] A. Vandermeulen, B. van der Heijde, L. Helsen, Controlling district heating and cooling networks to unlock flexibility: a review, Energy 151 (March) (2018) 103-115. https://doi.org/10.1016/j.energy.2018.03.034.

[35] Varmelast, n.d., Varmelast.dk., 1, 2020 n.d., Retrieved February from https:// www.varmelast.dk/en/dh-network. Accessed: February 2020.

[36] V. Verda, F. Colella, Primary energy savings through thermal storage in district heating networks, Energy 36 (7) (2011) 4278-4286. https://doi.org/10.1016/j. energy.2011.04.015.

[37] M. Wetter, M. Bonvini, T.S. Nouidui, Equation-based languages - a new paradigm for building energy modeling, simulation and optimization, Energy Build. (2015). https://doi.org/10.1016/j.enbuild.2015.10.017.

[38] M. Wetter, W. Zuo, T.S. Nouidui, Modeling of heat transfer in rooms in the Modelica "buildings" library. In Building Simulation 2011, in: 12th Conference of International Building Performance Simulation Association, Sydney, 2011, pp. 1096-1103.

[39] M. Wetter, W. Zuo, T.S. Nouidui, X. Pang, Modelica buildings library, J. Build Perform. Simul. 7 (4) (2014) 253-270. https://doi.org/10.1080/19401493.2013. 765506 . 